\title{
Dengue viruses binding proteins from Aedes aegypti and Aedes polynesiensis salivary glands Van-Mai Cao-Lormeau
}

Address: Head, Laboratoire de Recherche en Virologie Médicale, Institut Louis Malardé, Po Box 30, 98713 Papeete, Tahiti, French Polynesia Email: Van-Mai Cao-Lormeau - mlormeau@ilm.pf

Published: 25 March 2009

Virology Journal 2009, 6:35 doi:10.1186/1743-422X-6-35

This article is available from: http://www.virologyj.com/content/6/1/35

Cao-Lormeau; licensee BioMed Central Ltd.

This is an Open Access article distributed under the terms of the Creative Commons Attribution License (http://creativecommons.org/licenses/by/2.0), which permits unrestricted use, distribution, and reproduction in any medium, provided the original work is properly cited.

Received: 8 October 2008

Accepted: 25 March 2009

\begin{abstract}
Dengue virus (DENV), the etiological agent of dengue fever, is transmitted to the human host during blood uptake by an infective mosquito. Infection of vector salivary glands and further injection of infectious saliva into the human host are key events of the DENV transmission cycle. However, the molecular mechanisms of DENV entry into the mosquito salivary glands have not been clearly identified. Otherwise, although it was demonstrated for other vector-transmitted pathogens that insect salivary components may interact with host immune agents and impact the establishment of infection, the role of mosquito saliva on DENV infection in human has been only poorly documented. To identify salivary gland molecules which might interact with DENV at these key steps of transmission cycle, we investigated the presence of proteins able to bind DENV in salivary gland extracts (SGE) from two mosquito species. Using virus overlay protein binding assay, we detected several proteins able to bind DENV in SGE from Aedes aegypti (L.) and Aedes polynesiensis (Marks). The present findings pave the way for the identification of proteins mediating DENV attachment or entry into mosquito salivary glands, and of saliva-secreted proteins those might be bound to the virus at the earliest step of human infection. The present findings might contribute to the identification of new targets for anti-dengue strategies.
\end{abstract}

\section{Findings}

As the third millennium begins, classic dengue fever and the more severe dengue hemorrhagic fever and dengue shock syndrome, are still world public health concerns. Every year, dengue virus (DENV) infects more than 50 million people, with approximately 22000 fatal cases [1]. There are four antigenically distinct, but related, serotypes of DENV, a Flavivirus member of the family Flaviviridae. There is currently no vaccine available against DENV and vector control strategies fail to prevent the emergence of dengue epidemics, therefore new anti-dengue strategies need to be explored. A better understanding of the mechanisms and the molecules involved in the key steps of the DENV transmission cycle may lead to the identification of new anti-dengue targets.
DENV is transmitted by Aedes (Stegomyia) mosquitoes, principally Ae aegypti but also Ae albopictus and some endemic vectors like Ae polynesiensis in French Polynesia [2-4]. Infection of the female mosquito occurs during a blood feeding on a viremic human host. During the ten days following the ingestion of the infectious blood meal, viral replication occurs in different mosquito tissues and the virus finally infects the salivary glands [5-7]. Infection of mosquito salivary glands and subsequent injection of infectious saliva into the human host are key events of DENV transmission cycle.

In the present study, we investigated the presence of proteins able to bind to DENV in salivary gland extracts (SGE) from the Ae aegypti Bora-Bora strain (provided by the IRD, 
Montpellier, France) and an Ae polynesiensis wild colony from Atimaono-Tahiti (reared in our laboratory since 2000).

The salivary glands from 3-15 day-old adult females were dissected in phosphate buffer saline (PBS) $20 \mathrm{mM}$ and immediately transferred into a vial containing a lysis buffer $\left(1.5 \mathrm{mM} \mathrm{MgCl}_{2}, 10 \mathrm{mM}\right.$ Tris-HCl, $10 \mathrm{mM} \mathrm{NaCl}$, and $1 \%$ Nonidet P-40) and protease inhibitors $(2 \mathrm{mM}$ EDTA, $0.5 \mathrm{mM}$ phenylmethylsulfonyl fluoride and $10 \mu \mathrm{g} /$ $\mathrm{ml}$ of aprotinine). Each vial contained about 1,500 pairs of salivary glands and was stored at $-80^{\circ} \mathrm{C}$ until needed [8]. Salivary glands were then thawed and disrupted by sonication in an ice-water bath before being centrifugated at $9,000 \times g$ for 15 minutes at $4{ }^{\circ} \mathrm{C}$. The supernatant containing SGE was recovered for protein quantification and stored at $-80^{\circ} \mathrm{C}$ [9]. To prepare semi-purified virus, the four reference strains of DENV (type 1, [Hawaii, Hawaii 1944]; type 2, [New Guinea C, Hawaii 1944]; type 3, [H87, Philippines 1956]; type 4, [H-241, Philippines 1956]) and a clinical isolate obtained during the 1979 DEN4 epidemic in French Polynesia (amplified two times on Ae albopictus $\mathrm{C} 6 / 36$ cell cultures and stored at $-80^{\circ} \mathrm{C}$ ), were inoculated into the brain of suckling mice [10]. Mouse brain viral antigen extracts were then clarified by centrifugation at $12,000 \times g$ for 5 minutes and supernatants were applied into a discontinuous gradient of $65 \%$ and $15 \%$ $(\mathrm{w} / \mathrm{w})$ sucrose in GNTE buffer $(200 \mathrm{mM}$ Glycine, $100 \mathrm{mM}$ $\mathrm{NaCl}, 50 \mathrm{mM}$ Tris- $\mathrm{HCl}, 1 \mathrm{mM}$ Ethylene diamine tetracetate [EDTA]). Sucrose gradients were centrifuged at 21,500 $\times g$ for 3.5 hours at $4{ }^{\circ} \mathrm{C}$. The visible band containing the viruses was removed, diluted with GNTE and pelleted by centrifugation at $16,500 \times g$ for 2 hours at $4^{\circ} \mathrm{C}$. Finally the viral pellet was resuspended in GNTE and stored at $-80^{\circ} \mathrm{C}$ $[11,12]$. For Virus Overlay Protein Binding Assay (VOPBA) total proteins from SGE were separated by SDS$10 \%$ polyacrylamide gel electrophoresis (PAGE), in non reducing conditions, before being transferred onto a nitrocellulose membrane [13]. Membrane sheets (one lane per sheet) were then incubated in PBS-5\% (w/v) skim milk overnight at $4{ }^{\circ} \mathrm{C}$. The membranes were then blocked in PBS-0.5\% (w/v) Tween 20-5\% skim milk for 1 hour at $37^{\circ} \mathrm{C}$, followed by a first wash with PBS-0.5\% Tween 20 for 5 minutes followed by an additional wash with a highsalt wash-buffer (PBS, $0.5 \%$ Tween 20, 1\% skim milk, 220 $\mathrm{mM} \mathrm{NaCl}$ ). Membranes were then incubated for 3 hours at $37^{\circ} \mathrm{C}$ with DENV antigen extracts diluted in high-salt wash-buffer to obtain a final titre of $7.3 \log _{10} \mathrm{TCID}_{50} / \mathrm{ml}$. Virus binding was then detected indirectly by incubating nitrocellulose membranes with either anti-DENV typespecific hyperimmune mouse ascitic fluid (HMAF) or anti-envelop (E) protein type-specific monoclonal antibodies (Mabs). After incubation with horseradish peroxidase conjugated sheep anti-mouse IgG, DENV binding was visualized on X-ray film using an enhanced chemiluminescent (ECL) substrate.
VOPBA experiments were first performed using HMAF. Four proteins of 77, 58, 54 and 37 kilodaltons $(\mathrm{kDa})$ able to bind to the reference strains of the four DENV serotypes were detected in SGE from Ae aegypti (Figure 1). Because the DENV reference strains had been maintained and passaged for many years in laboratories, we also performed the experiment using a DEN4 clinical isolate. All of the proteins previously detected with the reference strains also appeared with the clinical isolate. VOPBA experiments were then performed using anti-E DEN1 or DEN4 specific Mabs. In SGE from Ae aegypti, the four proteins previously observed with HMAF and an additional protein of $67 \mathrm{kDa}$ were detected (Figure 2). In SGE from Ae polynesiensis, five proteins of $67,56,54,50$ and $48 \mathrm{kDa}$, were able to bind to DEN1 and DEN4 reference strains (Figure 3).

This is the first report on the presence of proteins able to bind to the four DENV serotypes in mosquito salivary gland extracts. Because SGE might contain both salivary gland tissue (basal lamina or salivary gland epithelial cells) and saliva-secreted proteins, the present work initiates the identification of either proteins mediating DENV infection of mosquito salivary glands or proteins bound to the virus at the early step of human infection.

DENV dissemination into mosquito tissues is dependant on the ability of the virus to penetrate several barriers: the midgut infection barrier (MIB), the midgut escape barrier (MEB) and the salivary glands. However, little is known about the mechanism and the molecules that allow the

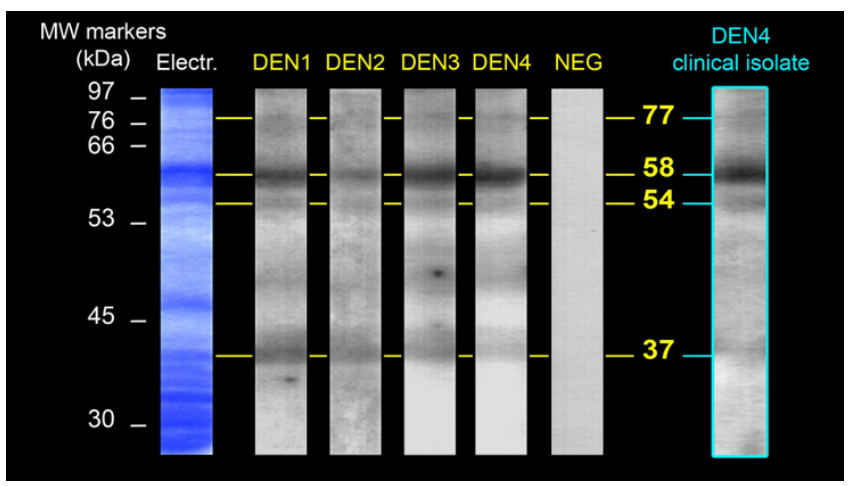

Figure I

DENV-binding proteins from Ae aegypti salivary glands detected with anti-DENV polyclonal antibodies. Total proteins from Ae aegypti salivary gland extracts were separated on a SDS-PAGE (Electr) and transferred onto a nitrocellulose membrane. Membrane sheets were then incubated with either: DENV reference strains (DENI to DEN4); a semi-purified non-inoculated suckling mouse brain extract (NEG); or a DEN4 clinical isolate. Virus binding was detected using anti-DENV HMAF. Migration of the molecular weight markers and the estimated size of the DENV-binding proteins are indicated in kilodaltons $(\mathrm{kDa})$, respectively on the left and on the right side of the figure. 


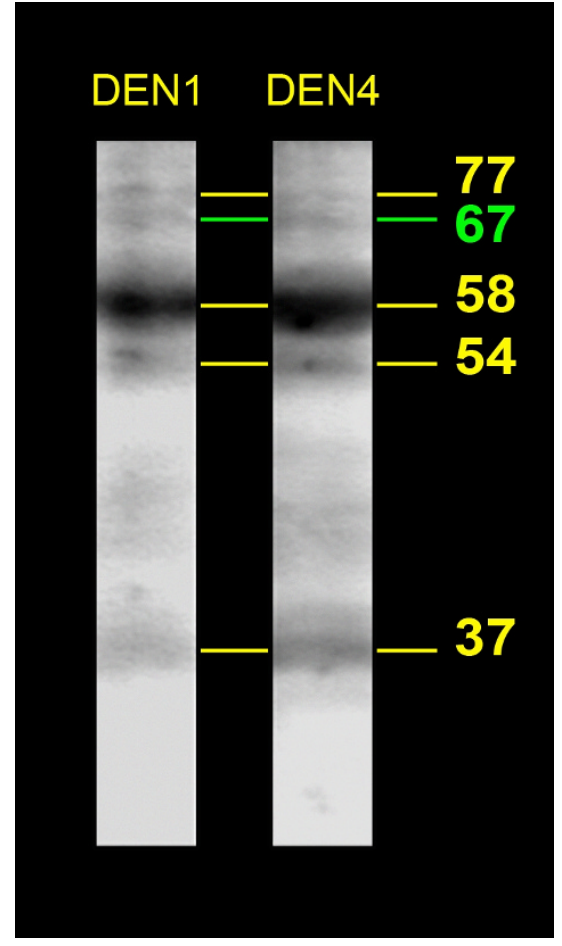

Figure 2

DENV-binding proteins from Ae aegypti salivary glands detected with anti-E monoclonal antibodies. Total proteins from Ae aegypti salivary gland extracts were treated as described in Figure I. After transfer, membrane sheets were incubated with either: DENI or DEN4 reference strains. Virus binding was then detected using anti-E Mabs. The estimated size of the DENV-binding proteins are indicated in kilodaltons $(\mathrm{kDa})$ on the right side of the figure.

virus to pass these barriers. Most of the studies designed to identify putative DENV-receptors in mosquito tissues have been performed using the Ae albopictus C6/36 cell line model [14-16]. There are only few reports on the isolation of such receptors in whole mosquito tissues. Yazi Mendoza et al. (2002) first described the presence of a DEN4-binding protein in mosquito tissues (head, thorax and abdomen), more recently Mercado-Curiel et al. (2006) report the isolation of two DENV putative receptors in midgut extracts from Ae aegypti $[12,17]$. However, receptors for all DENV serotypes in mosquito salivary glands have never been formally identified. Therefore, the next step to the present work would be to characterise the proteins that might be involved in DENV infection of $A e$ aegypti and Ae polynesiensis salivary glands. Once identified, such receptors would constitute key targets for transmission blocking strategies still explored for other vectortransmitted pathogens. As an example, the use of antibodies directed to Plasmodium sporozoïtes-receptors prevented the invasion of mosquito salivary glands by the parasite $[18,19]$.

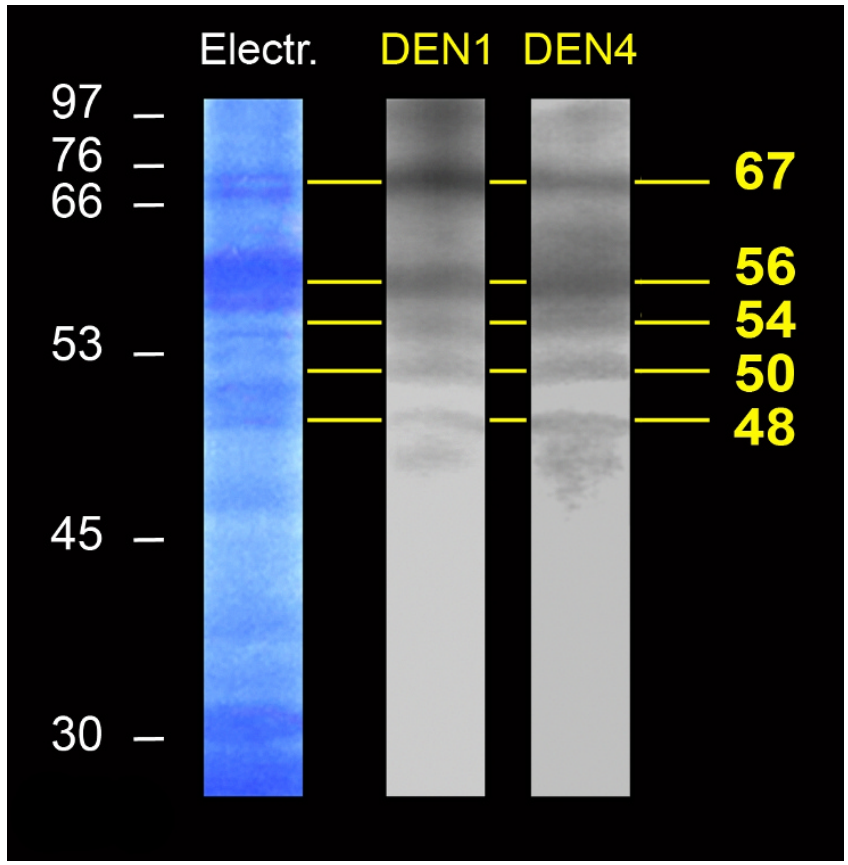

Figure 3

DENV-binding proteins from Ae polynesiensis salivary glands detected with anti-E monoclonal antibodies. Ae polynesiensis salivary gland extracts were treated as described for Ae aegypti in Figures I and 2. After the membrane sheets had been incubated with either the DENI or DEN4 reference strains, DENV binding was detected using anti-E type specific Mabs. Migration of the molecular weight markers and the estimated size of the DENV-binding proteins are indicated in kilodaltons $(\mathrm{kDa})$, respectively on the left and on the right side of the figure.

The saliva of several mosquito species has been well studied for its anti-haemostatic properties allowing efficient blood feeding [20]. The presence of pharmacologically active molecules such as platelet aggregation inhibitors, vasodilator agents and anti-coagulants have been described for Ae aegypti saliva [8,21-24]. The effect of the saliva from pathogen-transmitting arthropods on mammal host immune response and the establishment of the pathogen has also been investigated. There are several reports on the tick or the sand fly saliva to enhance bacterial, viral or parasite infections [25]. However, there has been little study on the arbovirus/mosquito saliva pair $[26,27]$. Using an in vivo mouse model it was recently demonstrated that mosquito feeding or mosquito saliva potentiates West Nile virus infection [28]. When focusing on the DENV/Ae aegypti pair, the only report is an in vitro study on human dendritic cells showing an inhibitory effect of vector saliva on DENV infection [29]. Because of the absence of a reliable animal model, the impact of $A e$ aegypti saliva on DENV infection in the human host remains unknown. The identification of mosquito sali- 
vary proteins able to form complexes with DENV would lead to new hypotheses on the role of vector saliva on the establishment of viral infection. Such complexes would be a live illustration of the conceptual surface-mosaic model that address the potential significance of protein adsorption to the surface of micro-organisms at the early phase of host-pathogen relationships [30].

\section{Competing interests}

The author declares that they have no competing interests.

\section{Acknowledgements}

We are grateful to Pr Christian Herbaut (Université de la Polynésie Française), Yves Séchan, Albert Tetuanui and Jerôme Viallon (Institut Louis Malardé) for their contribution to the present work. We are also grateful to Dr Nick Karabatsos (CDC, Atlanta, USA) for providing anti-E monoclonal antibodies.

\section{References}

I. World Health Organization: Impact of Dengue. www.who.int/csr/disease/dengue/impact/en/index.html].

2. Bancroft TL: On the aetiology of dengue fever. Australian Medical Gazette 1906, 25:17-18.

3. Cleland JB, Bradley B, McDonald W: Dengue fever in Australia. Its history and clinical course, its experimental transmission by Stegomyia fasciata, and the results of inoculation and other experiments. J Hyg 1918, 16:317-418.

4. Rosen L, Rozeboom LE, Sweet BH, Sabin AB: The transmission of dengue by Aedes polynesiensis Marks. Am J Trop Med Hyg I954, 3:878-882.

5. Kuberski T: Fluorescent antibody studies on the development of dengue-2 virus in Aedes albopictus (Diptera: Culicidae). J Med Entomol 1979, 16:343-349.

6. Linthicum KJ, Platt K, Myint KS, Lerdthusnee K, Innis BL, Vaughn DW: Dengue 3 virus distribution in the mosquito Aedes aegypti: an immunocytochemical study. Med Vet Entomol 1996, 10:87-92.

7. Salazar MI, Richardson JH, Sanchez-Vargas I, Olson KE, Beaty BJ: Dengue virus type 2: replication and tropisms in orally infected Aedes aegypti mosquitoes. BMC Microbiol 2007, 7(9):.

8. Stark $K R$, James $A A$ : Isolation and characterization of the gene encoding a novel factor $\mathrm{Xa-directed} \mathrm{anticoagulant} \mathrm{from} \mathrm{the}$ yellow fever mosquito, Aedes aegypti. J Biol Chem 1998, 273(33):20802-20809.

9. Bradford $M M: A$ rapid and sensitive method for the quantitation of microgram quantities of protein utilizing the principle of protein-dye binding. Anal Biochem 1976, 72:248-254

10. Parc F, Tetaria C, Pichon G: Dengue outbreak by virus type 4 in French Polynesia. Part II - Preliminary biological observations on epidemiology and physiopathology of the disease [in french]. Médecine Tropicale 1981, 4 I(I):97-102.

II. Cardosa MJ, Hooi TP, Shaari NS: Development of a dot enzyme immunoassay for dengue 3: a sensitive method for the detection of antidengue antibodies. J Virol Methods I988, 22:81-88.

12. Yazi Mendoza M, Salas-Benito JS, Lanz-Mendoza H, Hernández-Martínez S, Del Angel RM: A putative receptor for dengue virus in mosquito tissues: localization of a 45-Kda glycoprotein. Am J Trop Med Hyg 2002, 67(I):76-84.

13. Ludwig GV, Kondig JP, Smith JF: A putative receptor for venezuelan equine encephalitis virus from mosquito cells. J Virol I996, 70:5592-5599.

14. Salas-Benito JS, Del Angel RM: Identification of two surface proteins from C6/36 cells that bind dengue type 4 virus. J Virol 1997, 7 I (10):7246-7252.

15. Munoz ML, Cisneros A, Cruz J, Das P, Tovar R, Ortega A: Putative dengue virus receptors from mosquito cells. FEMS Microbiol Lett 1998, 1 68:251-258.

16. Reyes-del Valle J, Del Angel RM: Isolation of putative dengue virus receptor molecules by affinity chromatography using a recombinant E protein ligand. J Virol Methods 2004, I | 6(I):95-102.
17. Mercado-Curiel RF, Esquinca-Avilés HA, Tovar R, Diaz-Badillo A Camacho-Nuez M, Munoz ML: The four serotypes of dengue recognize the same putative receptors in Aedes aegypti midgut and Ae. albopictus cells. BMC Microbiol 2006, 6(85):.

18. Brennan JDG, Kent M, Dhar R, Fujioka H, Kumer N: Anopheles gambiae salivary gland proteins as putative targets for blocking transmission of malaria parasites. Proc Natl Acad Sci USA 2000 , 97:13859-13864.

19. Korochkina S, Barreau C, Pradel G, Jeffery E, Li J, Natarajan R, Shabanowitz J, Hunt D, Frevert U, Vernick KD: A mosquito-specific protein family includes candidate receptors for malaria sporozoites invasion of salivary glands. Cell Microbiol 2006 , 8(I): $163-175$

20. Champagne DE: Antihemostatic Molecules from saliva of blood-feeding arthropods. Pathophysiol Haemost Thromb 2005, 34:22I-227.

21. Ribeiro JM, Sarkis JJF, Rossignol PA, Spielman A: Salivary apirase of Aedes aegypti: Characterization and secretory fate. Comp Biochem Physiol B 1984, 79:81-86.

22. Ribeiro JM: Characterization of a vasodilator from the salivary glands of the yellow fever mosquito Aedes aegypti. J Exp Biol 1992, 165:6I-7|.

23. Champagne DE, Ribeiro JM: Sialokinins I and II: vasodilatory tachykinins from the yellow fever mosquito Aedes aegypti. Proc Natl Acad Sci USA 1994, 9 I: I 38- I 42.

24. Champagne DE, Smartt CT, Ribeiro JM, James AA: The salivary gland-specific apyrase of the mosquito Aedes aegypti is a member of the 5'-nucleotidase family. Proc Natl Acad Sci USA 1995, 92:694-698.

25. Titus RG, Bishop JV, Mejia JS: The immunomodulatory factors of arthropod saliva and the potential for these factors to serve as vaccine targets to prevent pathogen transmission. Parasite Immunol 2006, 28: I3|-|4I.

26. Osorio JE, Godsey MS, Defoliart GR, Yuill TM: La Crosse viremias in white-tailed deer and chipmunks exposed by injection or mosquito bite. Am J Trop Med Hyg 1996, 54(4):338-342.

27. Limesand KH, Higgs S, Pearson LD, Beaty BJ: Potentation of vesicular stomatitis New Jersey virus infection in mice by mosquito saliva. Parasite Immunology 2000, 22(9):46 I-46.

28. Schneider BS, Soong L, Girard YA, Campbell G, Mason P, Higgs S: Potentiation of West Nile Encephalitis by mosquito feeding. Viral Immunol 2006, I 9(I):74-82.

29. Ader DB, Celluzzi C, Bisbing J, Gilmore L, Gunther V, Peachman KK, Rao M, Barvir D, Sun W, Palmer DR: Modulation of dengue virus infection of dendritic cells by Aedes aegypti saliva. Viral Immunol 2004, I 7(2):252-265.

30. Mejia JS, Moreno F, Muskus C, Vélez ID, Titus RG: The surfacemosaic model in host-parasite relationships. Trends Parasitol 2006, 20(I I):508-5 I0.

\section{Publish with Bio Med Central and every scientist can read your work free of charge}

"BioMed Central will be the most significant development for disseminating the results of biomedical research in our lifetime. "

Sir Paul Nurse, Cancer Research UK

Your research papers will be:

- available free of charge to the entire biomedical community

- peer reviewed and published immediately upon acceptance

- cited in PubMed and archived on PubMed Central

- yours - you keep the copyright
BioMedcentral 